\title{
グロー放電質量分析法によるアルミニウム合金分析 での放電ガスの選択
}

\author{
伊藤 真二**山田 圭* ·小林 剛* \\ Selection of Discharge Gases for Analysis of Aluminum Alloys by Glow Discharge Mass Spectrometry \\ Shinji Iтон, Katsura Yamada and Takeshi KоваYаSH
}

Synopsis : Analysis of aluminum (Al) alloys was carried out using helium and argon/glow discharge mass spectrometry (He/GD-MS, and Ar/GD-MS). The relative sensitivity factors $\mathrm{RSF}_{\mathrm{X}, \mathrm{Al}}$ over the $\mathrm{Al}$ matrix used for GD-MS quantitative analysis were determined using six commercial $\mathrm{Al}$ alloy standard reference materials. The analytes comprise 15 elements containing in $\mathrm{Al}$ alloys: beryllium (Be), magnesium ( $\mathrm{Mg})$, silicon ( $\mathrm{Si}$ ), titanium (Ti), vanadium $(\mathrm{V})$, chromium $(\mathrm{Cr})$, manganese $(\mathrm{Mn})$, iron $(\mathrm{Fe})$, nickel $(\mathrm{Ni})$, copper $(\mathrm{Cu})$, zinc $(\mathrm{Zn})$, strontium $(\mathrm{Sr})$, tin $(\mathrm{Sn})$, lead $(\mathrm{Pb})$, and bismuth (Bi). A glow discharge cell for disk samples was used. A 12-mm internal diameter sample mask made from Ta was employed as the part of the anode. The discharge current was 3-mA for both of discharge gas. Large dispersion was observed in several obtained RSF values, resulting from insufficient validity of certified values of some elements such as Be. Nevertheless, the dispersion in RSF values was $8 \%$ or less as RSD for most of the analytes. The Ar/glow discharge was suitable for analysis of Al alloys because the RSF-values almost were better than those obtained by measurement using the He/glow discharge. Values obtained by GD-MS for a practical Al alloy A356 well agreed with the chemical analysis result, from alloying elements like $\mathrm{Si}$, minor components such as $\mathrm{Mg}$ and $\mathrm{Ti}$, to trace elements of parts per million level. Moreover, regarding the accuracy of GD-MS analysis, minor components such as $\mathrm{Mg}$, Ti, and Fe can be determined within about $2 \%$ accuracy as RSD, and trace elements below a single mass ppm within 5\%, except for Cr (RSD: 24.4\%), Ni (9.8\%), and $\mathrm{Sn}(13.3 \%)$. We established an eco-friendly analytical method without acid-decomposition by chemical reagents.

Key words : relative sensitivity factor; aluminum alloys; helium/glow discharge; argon/glow discharge; mass spectrometry; eco-friendly analysis.

\section{1. 緒言}

アルミニウム $(\mathrm{Al})$ はマグネシウム $(\mathrm{Mg})$ と同様に, 軽量 で加工性が良いという特長があり, 合金元素としてけい素 (Si) を添加することで耐摩耗性を, マンガン $(\mathrm{Mn})$ 添加で高 強度, 耐食性などの機能特性を与えている。 $\mathrm{Al}-\mathrm{Mg}$ 系や ジュラルミンという名称で知られる $\mathrm{Al}-\mathrm{Zn}-\mathrm{Mg}-\mathrm{Cu}$ 系合金 は, 耐食性を有する高強度材料として航空機産業などで広 く利用され，これら合金の新しい材料開発動向が示されて いる1)。一般的に $\mathrm{A} 1$ 合金では材料加工に展伸法あるいは鋳 造法が用いられるので, それら加工法に適応する合金元素 が添加され，さまざまな合金が開発されている。

材料の機能特性を左右する, 合金添加元素濃度や微量不 純物元素濃度の制御が重要であり，それに対応してこれら の高感度・高精度な定量分析が要求されている。日本工業 規格 (JIS)においては, 例えば鉄 $(\mathrm{Fe})$ 定量方法 ${ }^{2}$ では $1,10-$ フェナントロリン吸光光度法の定量下限は 0.002 質量 $\%$ (mass\%), 原子吸光分析方法 ${ }^{3)}$ の定量下限は 0.005 mass\% と 規定されている。多元素同時分析法としてよく利用されて いる誘導結合プラズマ(ICP)発光分析法(ICP-OES)の規格 ${ }^{4)}$

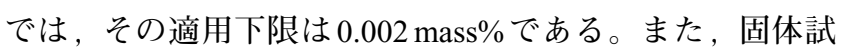
料直接分析法であるスパーク放電発光分光分析法では, ア ルゴン雾囲気放電発光スタンドを使用する方法 ${ }^{5}$ で $\mathrm{Fe}$ の定 量濃度範囲は 0.001 以上 2.5 mass \%となっている。これら の分析法は微量濃度域では十分な分析感度を有するとは言 いがたい。

一方, グロー放電質量分析法(GD-MS)は高感度な固体試 料の直接分析法であり,これまで各種合金中の合金元素お よび微量元素定量が報告されている ${ }^{6-10)}$ 。GD-MSでは放電 ガスとしてアルゴン $(\mathrm{Ar}) を$ 用いるのが一般的であるがアー

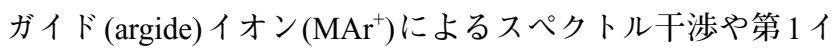
オン化エネルギー $\left(I P_{1}\right)$ が大きい, ガス形成元素などのイオ ン化が十分でないことが示された。新たなプラズマイオン 源としてへリウム $(\mathrm{He})$ を用いた一連の報告 ${ }^{11-13)}$ が見られ， スペクトル干渉の影響が少なく, ガス形成元素などのイオ ン化に有効であるプラズマであることが示されている。

本報告ではHeおよび $\mathrm{Ar}$ グロー放電により, $\mathrm{Al}$ 合金標準 物質 6 種を測定し，それぞれの測定で得られた $\mathrm{Al}$ マトリッ クスに対する各元素の相対感度係数 $\left(\mathrm{RSF}_{(\mathrm{X}, \mathrm{Al})}\right)$ を求めた。 それぞれの放電に打けるマトリックスイオン電流值の大き 
さ，得られたRSF值の評価およびスペクトル干渉の有無な どを考虑して，A1合金分析のための放電ガスとしてどち らが優位であるかについて検討した。さらに，これらの值 を用いて実用合金A356のイオン強度比を補正し，GD-MS 定量值を求めた。

また，GD-MS定量值を化学分析值およびファンダメン タル・パラメータ蛍光 X線分析 (FP-XRF) 值と比較し, そ の定量值の精度，正確さなどを確認した。それぞれの分析 法の有用性を示すことで，鉱酸などの試薬を使用しない， 環境にやさしい固体試料直接分析法の確立を目的とした。

以上述べたように, $\mathrm{He}(\mathrm{Ar}) / \mathrm{GD}-\mathrm{MS} に よ る \mathrm{Al}$ 合金中のべ リリウム $(\mathrm{Be}), \mathrm{Mg}, \mathrm{Si}$, チタン $(\mathrm{Ti})$, バナジゥム $(\mathrm{V})$, クロム $(\mathrm{Cr}), \mathrm{Mn}, \mathrm{Fe}$ ，ニッケル $(\mathrm{Ni})$, 銅 $(\mathrm{Cu})$, 带鉛 $(\mathrm{Zn})$, ストロンチ ウム $(\mathrm{Sr})$ ，すず $(\mathrm{Sn})$, 鉛 $(\mathrm{Pb})$ およびビスマス $(\mathrm{Bi})$ の 15 元素の 定量分析について検討し，その結果について報告する。

\section{2. 実験方法}

\section{$2 \cdot 1$ 装置および測定条件}

実験にはサーモフィッシャー・サイエンティフィック社 製VG 9000 二重収束型質量分析計を使用した。測定条件を Table 1に示した。グロー放電はいずれの放電ガスにおいて も, 定電流モード $3 \mathrm{~mA}$ で操作し, 放電電圧はガス導入量 を変化させることで $2 \mathrm{kV}$ ( $\mathrm{He}$ グロー放電 $), 1 \mathrm{kV}(\mathrm{Ar} ク ゙$ ロー放電）に調整した。放電セルはディスク試料用の Mega flat cell 用い, いずれも絶縁用窒化ホウ素を介して 液体窒素で冷却した。放電ガスには超高純度 He (99.9999\%) および $\mathrm{Ar}$ (99.9999\%)を用いた。ディスク試料の試料マス ク（ $\mathrm{Ta}$ 製：陽極の一部）は内径 $12 \mathrm{~mm}$ を用い，試料と陽 極の絶縁には内径 $20 \mathrm{~mm}$ のドーナツ型アルミナ板 $\left(\mathrm{Al}_{2} \mathrm{O}_{3}\right)$ を用いた。イオン電流の検出・測定にはファラデーカップ (Faraday 検出器) およびデイリー光電子增倍管・パルス計 数器 (Daly検出器) を用いた。各質量スペクトルは一定の 質量範囲の 60 ポイントを低質量側から走査し, 各ポイン

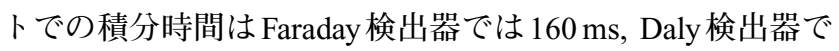
は $200 \mathrm{~ms}$ とした。質量分解能 $(\mathrm{m} / \Delta \mathrm{m}: 5 \%$ peak 高さ) は約 4000 に調整した。試料をイオン源チャンバーに挿入後, Heあるいは Arガスを導入し，イオン源チェンバーの圧力 が安定した後, グロー放電を点灯し，予備放電を行った。 炭素 $(\mathrm{C})$ や酸素 $(\mathrm{O})$ などガス形成元素の分析では十分な予 備放電が必要であるが, 本研究での予備放電時間はスパッ タリング速度が遅い $\mathrm{He}$ ガスの場合は $3.6 \mathrm{ks}$ (60 min), Arガ スの場合は $1.8 \mathrm{ks}(30 \mathrm{~min})$ とした。各元素のイオン電流值 はいずれも予備放電終了後, 測定 5 回の平均値とした。

比較分析に使用した蛍光 X線分析計は PANalytical 社製 PW2400で, 管球の印加電圧・電流, 分光結晶などの測定 条件は測定プログラム Super-Q (Ver. 3)での一般的な使用方 法に準拠し，使用した試料マスクは内径 $27 \mathrm{~mm}$, 各測定波
Table 1. Instrumental parameters of glow discharge mass spectrometer.

\begin{tabular}{cl}
\hline Mass spectrometer & Thermo Fisher Scientific VG 9000 \\
Mass resolution & $>4000(\mathrm{~m} / \Delta \mathrm{m}: 5 \%$ at peak height $)$ \\
Detector and & Faraday cup, 160ms/point \\
$\quad$ integration time & Daly multiplier-pulse counting, 200ms/point \\
Glow discharge & Constant current mode \\
Discharge current & $3 \mathrm{~mA}$ \\
Discharge voltage & $2000 \mathrm{~V}(\mathrm{He}), 1000 \mathrm{~V}(\mathrm{Ar})$ \\
Discharge cell & Mega flat cell \\
Discharge gas & He(99.9999\%), Ar $(99.9999 \%)$ \\
Pre-sputtering time & He:3.6ks(60min), Ar:1.8ks(30mim) \\
Sample mask & $12 \mathrm{~mm}($ inner diameter) \\
\hline
\end{tabular}

長での検出器の積分時間は4 12秒である。液体試料カッ プにポリプロピレンフィルム $(6.3 \mu \mathrm{m})$ を貼り，その上に試 料を乗せて測定した。得られたXRF測定データはFPプロ グラムUniQuant (Ver. 5) ${ }^{14)}$ で処理，定量した。Al合金の $\mathrm{XRF}$ 分析での各元素の感度係数 $\left(K_{i j}\right)$ はあらかじめ, 後述の $2 \cdot 2$ 節で示す $\mathrm{Al}$ 合金標準物質を同一条件で測定し，最適な 值に調整したものを使用した。

\section{$2 \cdot 2$ 試料および試料形状}

$\mathrm{Al}$ マトリックスに対する各元素の RSF 值算出のために A1合金標準物質6種（SS214-H, SS220-R, SS380-Y, SS5005E, SA1685, SA1769: Alcoa製）を使用し，それぞれの化学 組成を Table 2 に示した。試料表面の前処理は Arグロー放 電の場合は，測定面をジルコニア研磨布\#120を用いた乾

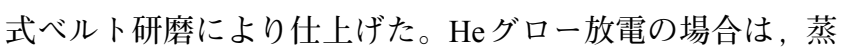
留水で $50 \mathrm{v} / \mathrm{v} \%$ に希釈したコロイダルシリカ（MASTERMET, BUEHLER 製） $30 \mathrm{~mL}$ に $\mathrm{H}_{2} \mathrm{O}_{2}$ を 2 3 $\mathrm{mL}$ を添加した溶 液を用いて鏡面研磨を施したが, Arグロー放電と比べて予 備放電での表面污染の除去に約 2 倍の時間を要した。すべ ての試料はエタノール洗浄後, 真空乾燥し, 測定に供した。

\section{3. 実験結果および考察}

\section{$3 \cdot 1$ 相対感度係数 $\left(\mathrm{RSF}_{\mathrm{X}, \mathrm{A}}\right)$}

Table 1 に示した測定条件で $\mathrm{Al}$ 合金標準物質 6 種を測定 し, 得られた各元素のイオン電流值を用いて, RSF值を次 式により算出した。

$$
R S F_{\mathrm{X}, \mathrm{S}}=\left(C_{\mathrm{X}} / C_{\mathrm{S}}\right) \times\left(I_{\mathrm{S}} / I_{\mathrm{X}}\right)
$$

ここで添字 XおよびSはそれぞれ分析元素および内標準元 素 $(\mathrm{Al})$ を，CおよびIはそれぞれ質量濃度 (mass\%) および同 位体比 ${ }^{15}$ 補正されたイオン電流值を表す。Table 3に $\mathrm{Al}$ マ トリックスでの各元素の RSF 值を He およびArグロー放電 について示した。Arグロー放電で $\mathrm{Cr}$ は， RSF值の RSDは 11.3\%とやや大きい值であった。また，Beについては2試 料の認証值が 0.003 および 0.006 mass\%で，計算された RSF 值はそれぞれ 0.421 および 0.669 であり，相対標準偏差 
Table 2. Chemical compositions of Al alloys Alcoa SRMs used for calculation of RSF values (GD-MS) and $K_{i j}$ coefficients (FP/XRF).

\begin{tabular}{|c|c|c|c|c|c|c|}
\hline \multirow[b]{2}{*}{ Element } & \multicolumn{6}{|c|}{ Certified values, $w$ (mass \%) } \\
\hline & SS214-H & SS220-R & SS380-Y & SS5005E & SA1685 & SA1769 \\
\hline $\mathrm{Be}$ & 0.003 & 0.006 & - & - & - & - \\
\hline Mg & 4.10 & 9.97 & 0.18 & 0.86 & 0.016 & 0.048 \\
\hline $\mathbf{S i}$ & 0.13 & 0.15 & 8.85 & 0.16 & $0.1^{* 1}$ & $0.1^{* 1}$ \\
\hline $\mathrm{Ti}$ & 0.11 & 0.11 & 0.11 & 0.027 & 0.035 & 0.064 \\
\hline V & - & - & - & - & 0.012 & 0.026 \\
\hline $\mathrm{Cr}$ & 0.032 & 0.001 & 0.002 & 0.021 & 0.033 & 0.081 \\
\hline Mn & 0.13 & 0.066 & 0.43 & 0.037 & 0.033 & 0.086 \\
\hline $\mathrm{Fe}$ & 0.20 & 0.18 & 0.87 & 0.46 & $0.1^{* 1}$ & $0.1^{* 1}$ \\
\hline $\mathrm{Ni}$ & 0.034 & 0.001 & 0.33 & 0.023 & 0.030 & 0.084 \\
\hline $\mathrm{Cu}$ & 0.047 & 0.12 & 3.58 & 0.061 & 0.032 & 0.092 \\
\hline $\mathbf{Z n}$ & 0.080 & 0.042 & 0.35 & 0.042 & 0.029 & 0.080 \\
\hline Sn & - & - & - & - & 0.029 & 0.079 \\
\hline $\mathbf{P b}$ & - & - & - & - & 0.029 & 0.080 \\
\hline $\mathbf{B i}$ & & - & - & & 0.028 & 0.078 \\
\hline $\mathrm{Al}^{\prime 2}$ & 95.03 & 89.43 & 85.70 & 98.05 & 98.91 & 98.36 \\
\hline
\end{tabular}

Table 3. RSF values for Ar glow discharge and He glow discharge obtained by Faraday and Daly detectors for the Al matrix.

\begin{tabular}{|c|c|c|c|c|}
\hline \multirow{3}{*}{ Element } & \multirow{2}{*}{\multicolumn{2}{|c|}{$\begin{array}{c}\text { Ar glow discharge } \\
\text { Mean } \operatorname{RSF}\left(\operatorname{RSF}_{X, A I}\right)\end{array}$}} & \multirow{2}{*}{\multicolumn{2}{|c|}{$\begin{array}{c}\text { He glow discharge } \\
\text { Mean } \operatorname{RSF}\left(\operatorname{RSF}_{\mathbf{X}, \mathrm{AI}}\right)\end{array}$}} \\
\hline & & & & \\
\hline & Daly & Faraday & Daly & Faraday \\
\hline${ }^{9} \mathrm{Be}$ & $0.545(32.2 \%, n=2)$ & - & $0.651(31.6 \%, n=2)$ & - \\
\hline${ }^{24} \mathrm{Mg}$ & $0.926(4.2 \%, n=4)$ & $0.919(3.7 \%, n=2)$ & $1.391(14.8 \%, n=4)$ & $0.883(6.8 \%, n=2)$ \\
\hline${ }^{27} \mathrm{Al}$ & $=1$ & $=1$ & $=1$ & $=1$ \\
\hline${ }^{28} \mathrm{Si}$ & $1.098(7.4 \%, n=3)$ & 1.189 & $1.357(9.2 \%, \mathrm{n}=3)$ & 0.988 \\
\hline${ }^{49} \mathrm{Ti}$ & $0.384(6.4 \%, n=6)$ & - & $2.813(7.7 \%, n=6)$ & - \\
\hline${ }^{51} \mathrm{~V}$ & $0.431(1.6 \%, n=2)$ & - & $2.135(5.6 \%, n=2)$ & - \\
\hline${ }^{52} \mathrm{Cr}$ & $1.244(11.3 \%, n=5)$ & - & $1.792(5.5 \%, n=5)$ & - \\
\hline${ }^{55} \mathrm{Mn}$ & $1.018(7.5 \%, n=6)$ & - & $2.526(7.1 \%, n=6)$ & -- \\
\hline${ }^{56} \mathrm{Fe}$ & $0.706(6.1 \%, n=4)$ & - & $2.434(2.8 \%, n=4)$ & - \\
\hline${ }^{60} \mathrm{Ni}$ & $1.070(4.5 \%, n=5)$ & - & $2.251(8.3 \%, n=5)$ & - \\
\hline${ }^{63} \mathrm{Cu}$ & $3.522(8.3 \%, n=6)$ & - & $2.398(5.6 \%, n=5)$ & 1.006 \\
\hline${ }^{66} \mathrm{Zn}$ & $3.598(5.9 \%, n=6)$ & - & $3.385(10 \%, n=6)$ & - \\
\hline${ }^{88} \mathrm{Sr}^{*}$ & 0.477 & - & 0.477 & - \\
\hline${ }^{119} \mathrm{Sn}$ & $2.168(0.4 \%, n=2)$ & - & $4.213(1.7 \%, n=2)$ & - \\
\hline${ }^{208} \mathrm{~Pb}$ & $2.828(7.6 \%, n=2)$ & - & $7.139(1.7 \%, n=2)$ & - \\
\hline${ }^{209} \mathrm{Bi}$ & $4.270(7.2 \%, n=2)$ & - & $6.080(1.1 \%, n=2)$ & - \\
\hline
\end{tabular}

Figures in parenthesis are relative standard deviation (RSD \%) and number of samples.

(RSD) として $32.2 \%$ と変動が大きかった。標準物質の制作 年がいずれも1960年代で, Beのみならず, 有効数字の桁 数が十分でないことがRSF值の変動の一因になっているも のと思われる。しかしながら，他の分析対象元素について はいずれの元素においても RSF值の変動は RSDで $8 \%$ 以下 であった。

一方, $\mathrm{He}$ グロー放電の場合は $\mathrm{Cu}$ を除いて全ての元素で RSF值の増加（相対的な感度の低下）が見られた。この原 因は $\mathrm{He} / \mathrm{GD}-\mathrm{MS}$ における高効率イオン化に関する報告 ${ }^{12)}$ 示したように, Heプラズマイオン源においては測定に用 いる 1 価イオン電流值に対して，～数 $10 \%$ に相当する 2 価 イオンを生成した，というデータから理解できる。マト リックス元素 $\mathrm{A} 1$ のイオン電流值は Arグロー放電および $\mathrm{He}$ グロー放電とも，ピーク面積積分值で $10^{-10} \sim 10^{-9} \mathrm{~A}$ とほほ
同などの值であった。

\section{$3 \cdot 2$ スペクトル干渉}

マトリックス元素扎よび放電ガス（ $\mathrm{Al}, \mathrm{He}$ 扎よび $\mathrm{Ar}$ あ るいは合金元素）に起因するスペクトル干渉の有無につい て検討した。

$\mathrm{Ar}$ グロー放電において, $\mathrm{Cu}$ は質量対電荷比 $(m / z) 63$ 打よ び 65 にはそれぞれ ${ }^{27} \mathrm{Al}^{36} \mathrm{Ar}^{+}$および ${ }^{27} \mathrm{Al}^{38} \mathrm{Ar}^{+}$で表わされる アーガイドイオンが高質量側に出現するが, いずれも本実 験条件で分離できるので, どちらの同位体を測定しても差 し支えなかった。また，Znについては $m / z 66$ および 68 を 測定したが, Si 合金元素として含む場合には後者には高 質量側に ${ }^{28} \mathrm{Si}^{40} \mathrm{Ar}^{+}$の大きなピークのために測定精度が前者 より悪くなることがわかった。そのほかのスペクトル干渉 としては, 本実験条件下ではスペクトルは分離することが でき，測定イオン電流值に影響しなかった。

$\mathrm{He}$ グロー放電においては例えば， $\mathrm{Fe}, \mathrm{Ni}$ などの2価イオ ンが Si P P, S などのピークの低質量側に出現するが本実験 条件下では分離可能であった。

以上述べたように $\mathrm{Al}$ 合金分析について $\mathrm{Ar}$ グロー放電お よびHeグロー放電で得られたデータから，1)スペクトル 干渉について両者とも大きな妨害はない，2)マトリックス イオン電流值はほぼ同じである，3) ガス形成元素が分析対 象ではない，ことから $\mathrm{He}$ グロー放電プラズマの特長が活 かせず，4)試料調整が簡便である，5)相対イオン電流值が 大きい（RSF值が小さい）ことから，Arグロー放電プラ ズマを使用する方が望ましいと判断した。

\section{$3 \cdot 3$ 実試料分析}

$\mathrm{Ar}$ グロー放電による実用 Al 合金A356の GD-MS 定量值, 化学分析值およびFP-XRF定量值を Table 4 に示した。化学 分析值はいずれも2回繰り返しの平均值である。 $\mathrm{Be}, \mathrm{Mg}$, Ti, V, Cr, Mn, Fe, Ni, Cu, Zn, Sn, Pb, Bi はアルミニウムおよ びアルミニウム合金の ICP-OES ${ }^{4}$ の A 法に準拠して，定量 
